\title{
Prepubertal Increases in Gonadotropin-releasing Hormone mRNA, Gonadotropin-releasing Hormone Precursor, and Subsequent Maturation of Precursor Processing in Male Rats
}

Clive M. Dutlow, Jonathan Rachman, Timothy W. Jacobs, and Robert P. Millar

Medical Research Council Regulatory Peptides Research Unit, Department of Chemical Pathology, University of Cape Town, Cape Town, South Africa

\begin{abstract}
Changes in gonadotropins and gonadal steroids during sexual maturation in rats and humans are well documented but little is known about hypothalamic gonadotropin-releasing hormone (GnRH) gene expression in relation to these events. This study measured hypothalamic proGnRH mRNA, GnRH precursor, and fully processed GnRH from postnatal day 8 until day 62 in male rats. GnRH precursor increased on day 22 , reached a peak on day 24, declined on day 25 and returned to infantile levels by day 28 . A secondary rise in precursor occurred at about day 40 when testosterone levels increased. GnRH mRNA increased on day 22 and remained elevated over the study period to day 26. GnRH increased on day 24 and remained at this level until a secondary rise occurred coincident with the testosterone rise at about day $\mathbf{4 0}$. The ratio of $\mathrm{GnRH}$ precursor to GnRH was high until day 24 and was low from day 26 onwards, reflecting a maturation of the processing enzyme system between these $2 \mathrm{~d}$. Thus, an abrupt increase in GnRH gene transcription (mRNA) occurs early in juvenile male rats (day 22), well before the onset of puberty. An increase in GnRH precursor accompanies these early changes and this is followed by the maturation of processing as evidenced by the rapid decline of precursor and increase in GnRH from day 24 onward. (J. Clin. Invest. 1992. 90:2496-2501.) Key words: gonadotropin-releasing hormone $\bullet$ gene expression $\bullet \mathrm{mRNA} \bullet$ postweaning $\bullet$ puberty
\end{abstract}

\section{Introduction}

The mechanisms underlying the onset of mammalian puberty have not been entirely elucidated. Although the ontogeny of hormone production postnatally is well defined, the intricacies of the central mechanisms underlying the ontogenetic changes are now being unraveled (for reviews see references 1-7).

Reproductive ability in the male rat is achieved around postnatal day 50 when testicular spermatogenesis occurs $(4,5$, $8,9)$. Spermatogenesis is brought about by increasing levels of gonadotropins in the circulation and adult levels of testicular androgen $(4,8,9)$. Increased circulating gonadotropin levels and adult pulsatile release profiles are a direct reflection of the

Address correspondence to Dr. Clive Dutlow, Department of Chemical Pathology, University of Cape Town Medical School, Observatory 7925, Cape Town, South Africa. 1992

Received for publication 6 January 1992 and in revised form 12 July

J. Clin. Invest.

(c) The American Society for Clinical Investigation, Inc.

$0021-9738 / 92 / 12 / 2496 / 06 \$ 2.00$

Volume 90, December 1992, 2496-2501 amount and pulsatile release patterns of hypothalamic gonadotropin-releasing hormone $(\mathrm{GnRH})^{1}(8,9)$.

Hypothalamic GnRH content shows a steady increase during the first 3 mo of life in the male rat (10-12). An increase in frequency of pulsatile GnRH secretion at the onset of puberty has been observed in a number of species, including rats (1316). Using hypothalamic explants from male rats, it has been shown that the frequency of pulsatile GnRH secretion in vitro was low on day 15 (i.e., before weaning) whereas an increase of nearly twofold occurred on day 25 (i.e., soon after weaning) $(12,17,18)$. In a recent study, it was shown that GnRH mRNA levels were low in both male and female rats in the infantile period (days 1-15) and elevated in the juvenile and peripubertal periods (days 30-60) (19).

We have now undertaken a study of the ontogeny of hypothalamic GnRH gene expression in the male rat by quantitating GnRH mRNA, GnRH precursor, and processed GnRH from infancy to adulthood. A significant increase in GnRH gene expression was demonstrated immediately after day 21 weaning, well in advance of major pubertal hormonal changes. This observation extends our understanding of the central events associated with pituitary and testicular hormonal changes that lead to puberty.

\section{Methods}

Experimental design. Male rats were killed at regular intervals between birth and adulthood. Hypothalami and serum from these rats were used for hormone RIAs. GnRH and GnRH precursor were measured in hypothalamic extracts and testosterone in the serum.

The period during which the greatest increase in $\mathrm{GnRH}$ precursor occurred was studied more thoroughly. Shorter time intervals between killing were chosen, larger numbers of animals were killed at each time interval, and GnRH mRNA levels in the hypothalami were determined in conjunction with $\mathrm{GnRH}$ precursor.

Animals and tissue collection. Male Long-Evans rats were housed under natural light/dark conditions and given food pellets and water ad libitum. Newborn animals were kept with their mothers until time of killing or weaned at day 21 . The animals were killed by decapitation in groups of six on postnatal day 5, 8,12,16, 20, and 24 and thereafter at 2-d intervals until day 62 .

After decapitation between 10 am and $12 \mathrm{pm}$, trunk blood was collected in glass tubes. After centrifugation at $5,000 \mathrm{~g}$ for $20 \mathrm{~min}$, serum samples were collected and stored in polyethylene tubes at $-20^{\circ} \mathrm{C}$ until assayed for hormones.

Immediately after decapitation, brains were removed and placed on a cold $\left(4^{\circ} \mathrm{C}\right)$ platform. With the ventral surface of the brain facing up, a coronal section was made $2 \mathrm{~mm}$ rostral from the anterior margin of the hypothalamic island. Another coronal section was performed $2 \mathrm{~mm}$ caudal to the median eminence. Incisions were made along the lateral

1. Abbreviations used in this paper: $\mathrm{GnRH}$, gonadotropin-releasing hormone; NPY, neuropeptide Y; PCR, polymerase chain reaction; POA, preoptic area. 
borders of the hypothalamic island between the two coronal sections and a block of hypothalamic tissue $3 \mathrm{~mm}$ deep was snap frozen on solid $\mathrm{CO}_{2}$. This tissue block included all the major regions containing GnRH neurons, including the preoptic area (POA), the anterior hypothalamus, the diagonal band of Broca, the medial septum, and the median eminence.

Peptide extraction and RIA. Each hypothalamus was homogenized with a Dounce homogenizer in $1 \mathrm{ml}$ of $2 \mathrm{~N}$ acetic acid and $1 \mathrm{mM}$ PMSF, incubated at $4^{\circ} \mathrm{C}$ for $30 \mathrm{~min}$, and centrifuged for $30 \mathrm{~min}$ at $18,000 \mathrm{~g}, 4^{\circ} \mathrm{C}$. The supernatant was lyophilized and reconstituted in RIA buffer (PBS gelatin) and frozen at $-20^{\circ} \mathrm{C}$ until assayed.

To quantitate the GnRH precursor, an antiserum (As 1947) raised against a synthetic peptide representing amino acids $6-16$ of the human GnRH precursor was used (20). The Gly-Lys-Arg cleavage and amidation site is contained in this sequence and is required for antibody binding $(20,21)$. Antiserum 1947 was used in the RIA at a final dilution of 1:40,000 together with ${ }^{125}$ I-labeled synthetic rat proGnRH$\mathrm{GAP}_{5-16}$ with standards of proGnRH-GAP $6-16$ (20). Half-maximal displacement of the assay $\left(E D_{50}\right)$ occurred at $26 \mathrm{pg}$ per tube with an intraassay coefficient of variation of $3.9 \%$. Fully processed $\mathrm{GnRH}$ was quantitated using antiserum $80 / 1$, which requires the $\mathrm{NH}_{2}$ and $\mathrm{COOH}$ termini of GnRH to be intact for binding (22) and which does not recognize the GnRH precursor (20). Antiserum $80 / 1$ was used in the RIA at a final dilution of 1:24,000 together with ${ }^{125}$ I-labeled synthetic GnRH. ED 50 occurred at 62 pg per tube with an intraassay coefficient of variation of $3.4 \%$. All samples were assayed in duplicate in a single assay with each antiserum.

Plasma testosterone quantitation. Plasma testosterone for all experimental samples was assayed in a single assay using tritiated testosterone as label and antiserum R67 at a final dilution of 1:8,000 (23). $E_{50}$ occurred at $2.4 \mathrm{nmol} /$ liter with an intraassay coefficient of variation of $4.1 \%$.

Postnatal days 21-26 GnRH $m R N A$ and precursor determination. To validate the increase in GnRH precursor observed on postnatal day 24 (see Fig. $1 a$ ), five hypothalami were pooled for a single extraction and three groups of five hypothalami were extracted on each experimental day. Furthermore, shorter time intervals (postnatal days 21, 22, 24 , and 26 or postnatal days 21,23 , and 25 ) were examined for both GnRH mRNA and precursor differences.

The very low number of GnRH neurones (400-800) in the hypothalamus $(24,25)$ and the small amounts of GnRH mRNA present $(10,000-20,000$ copies per adult rat perikarium) $(20)$ necessitated the dissection of a narrower tissue area than that used for peptide quantitation, to allow specific mRNA determination. With the ventral surface of the brain facing up, a coronal section was performed at the posterior border of the optic chiasm and another coronal section was made $3 \mathrm{~mm}$ rostral to the first. Lateral incisions were performed $1 \mathrm{~mm}$ inside the lateral borders of the hypothalamic island and a tissue block $3 \mathrm{~mm}$ deep was removed and placed in a 1.5 -ml polypropylene tube in solid $\mathrm{CO}_{2}$.

On each day of the experiment three groups of five hypothalami were collected on solid $\mathrm{CO}_{2}$ and stored at $-70^{\circ} \mathrm{C}$ until extracted with acetic acid and PMSF as above. The acetic acid supernatant was lyophilized and redissolved in PBS gelatin for GnRH precursor RIA as described above.

RNA was extracted from the acetic acid pellet from five hypothalami by the single-step method using acid guanidinium thiocyanate, phenol, and chloroform (26). The RNA was pelleted from the aqueous phase of the centrifuged extract $\left(10,000 \mathrm{~g}\right.$ for $30 \mathrm{~min}$ at $\left.4^{\circ} \mathrm{C}\right)$ with $1 \mathrm{vol}$ of isopropanol, dissolved in acid guanidinium thiocyanate once more, and reprecipitated with isopropanol. The pellet was washed twice with $70 \%$ ethanol $30 \%$ diethyl pyrocarbonate-treated $\mathrm{H}_{2} \mathrm{O}$ and redissolved in $500 \mu$ l diethyl pyrocarbonate $\mathrm{H}_{2} \mathrm{O}$.

$10 \mu$ l RNA (representing $10 \%$ of a hypothalamus) was used to quantitate the GnRH mRNA by a polymerase chain reaction (PCR)based assay. Negative and positive controls were assay tubes containing either no RNA or RNA from a cell line (GT1-7) that produces GnRH. The RNA was added to $15 \mu \mathrm{l}$ melting/annealing mix containing 50 pmol of a specific oligonucleotide cDNA primer directed against the
mRNA sequence encoding amino acids 58-63 of the GnRH precursor, heated to $90^{\circ} \mathrm{C}$ for $30 \mathrm{~s}$, and snap cooled on ice. $15 \mu \mathrm{l}$ of avian myeloblastoma virus (AMV) reverse transcriptase reaction mix containing 20 nmol of each dNTP, $1 \mathrm{U}$ of human placental ribonuclease inhibitor (Amersham Corp., Arlington Heights, IL), and $3 \mathrm{U}$ of AMV reverse transcriptase (Life Science Associates, Bayport, NY) was added to the cold RNA-containing annealing mix and incubation at $42^{\circ} \mathrm{C}$ was performed for $30 \mathrm{~min} .10 \mu \mathrm{l}$ of Taq polymerase reaction mix containing 0.7 pmol of ${ }^{32} \mathrm{P}$ end-labeled sense strand oligonucleotide equivalent to a 5 ' sequence of the GnRH ( $m R N A$ ) encoding amino acids 1-6 of the GnRH precursor and $1 \mathrm{U}$ of Taq polymerase (Promega Corp., Madison, WI) was added directly to the first-strand synthesis reaction. A paraffin oil overlay was applied and $15 \mathrm{PCR}$ cycles $\left(94^{\circ} \mathrm{C}\right.$ for $30 \mathrm{~s} ; 55^{\circ} \mathrm{C}$ for $2 \mathrm{~min} ; 72^{\circ} \mathrm{C}$ for $2 \mathrm{~min}$ ) were performed. After the addition of each of the three reaction mixes the solution was $1 \times$ with respect to reverse transcriptase Taq buffer (27) $(2.5 \times$ RT Taq buffer: $168 \mathrm{mM}$ Tris $\mathrm{HCl}$, $\mathrm{pH} 8.8$, at $25^{\circ} \mathrm{C}, 41.5 \mathrm{mM}\left[\mathrm{NH}_{4}\right]_{2} \mathrm{SO}_{4}, 16.8 \mathrm{mM} \mathrm{MgCl} 2,25 \mathrm{mM}$ $\beta$-mercaptoethanol, $0.42 \mathrm{mg} / \mathrm{ml} \mathrm{BSA}$ ). A $40-\mu \mathrm{l}$ aliquot of the doublestranded PCR product-containing reaction was carefully removed, transferred to another Eppendorf tube, and dried under vacuum. The dry pellet was dissolved in $5 \mu$ l sequencing gel application buffer, heated to $100^{\circ} \mathrm{C}$ for $1 \mathrm{~min}$ and loaded onto a $6 \%$ polyacrylamide, $50 \%$ urea, $1 \times$ Tris-borate $2 \mathrm{~m}$ methylenediamine tetraacetic acid (TBE) gel and subjected to electrophoresis at a constant current of $30 \mathrm{~mA}$ until the bromophenol blue (and end-labeled oligonucleotide) eluted from the bottom of the gel. Autoradiography was performed at $-70^{\circ} \mathrm{C}$ and the 191-bp PCR product was visualized on the $\mathrm{x}$-ray film. A piece of film of identical size, containing the developed silver grain band, was cut from each tract (representing the PCR product of one reaction). The developed silver grains were eluted from each piece of film with 1.0 $\mathrm{N} \mathrm{NaOH}$ at $37^{\circ} \mathrm{C}$ for $2 \mathrm{~h}$, transferred to a $30 \%$ glycerol solution, and the absorbance at $500 \mathrm{~nm}$ was measured immediately after mixing thoroughly (27a).

Blank pieces of film with the same dimensions as excised for the developed areas representing the labeled PCR product were also processed as outlined. The $\mathrm{OD}_{500}$ values obtained for these blank pieces of film were used for the subtraction of background from the film pieces representing the PCR product. Exposure times $(2-3 \mathrm{~h})$ that did not give maximal exposure of the most intense signals were chosen.

Northern blot analysis of POA RNA from juvenile rats (day 20 and day 24) was performed to confirm the PCR-based assay results. Dissections and RNA extraction were performed as for the PCR-based assay. The RNA from two groups of four pooled hypothalami was loaded onto a $1.4 \%$ denaturing agarose gel and subjected to electrophoresis until the bromophenol blue marker had migrated $3 \mathrm{~cm}$ from the well. The short electrophoretic migration distance resulted in sharper RNA bands on autoradiographs. A truncated synthetic rat GnRH mRNA served as a positive control for the blotting and probing protocols. The RNA was blotted onto Hybond $\mathrm{N}^{+}$nylon membrane (Amersham Corp.) in $0.05 \mathrm{~N} \mathrm{NaOH} .{ }^{32}$ P-labeled antisense rat GnRH RNA $\left(\sim 10^{9}\right.$ $\mathrm{cpm} / \mathrm{pg}$ ) was used to probe the blot for $18 \mathrm{~h}$ at $65^{\circ} \mathrm{C}$ in $50 \%$ Formamide, $5 \times \mathrm{SSPE}, 0.1 \% \mathrm{NaPPi}, 100 \mu \mathrm{g} / \mathrm{ml}$ sonicated salmon sperm DNA, after prehybridization for $15 \mathrm{~min}$ in the same solution at $65^{\circ} \mathrm{C}$. The blot was washed three times for $20 \mathrm{~min}$ with $200 \mathrm{ml}$ of $0.1 \times$ SSPE, $5 \mathrm{mM}$ EDTA ( $\mathrm{pH} \mathrm{8.0}$ ), 0.1\% SDS. The air-dried filter was autoradiographed at $-70^{\circ} \mathrm{C}$ for $7 \mathrm{~d}$.

Statistical analysis. The results shown are representative data from either a minimum of six individual rats of identical age (litter mates) or three groups of five rats of the same age. The Student's $t$ test for independent means was used to determine differences between experimental groups.

\section{Results}

During the infantile period (days 8-20) no significant change in either hypothalamic $\mathrm{GnRH}$ precursor and GnRH content or serum testosterone levels was observed (Fig. 1). 


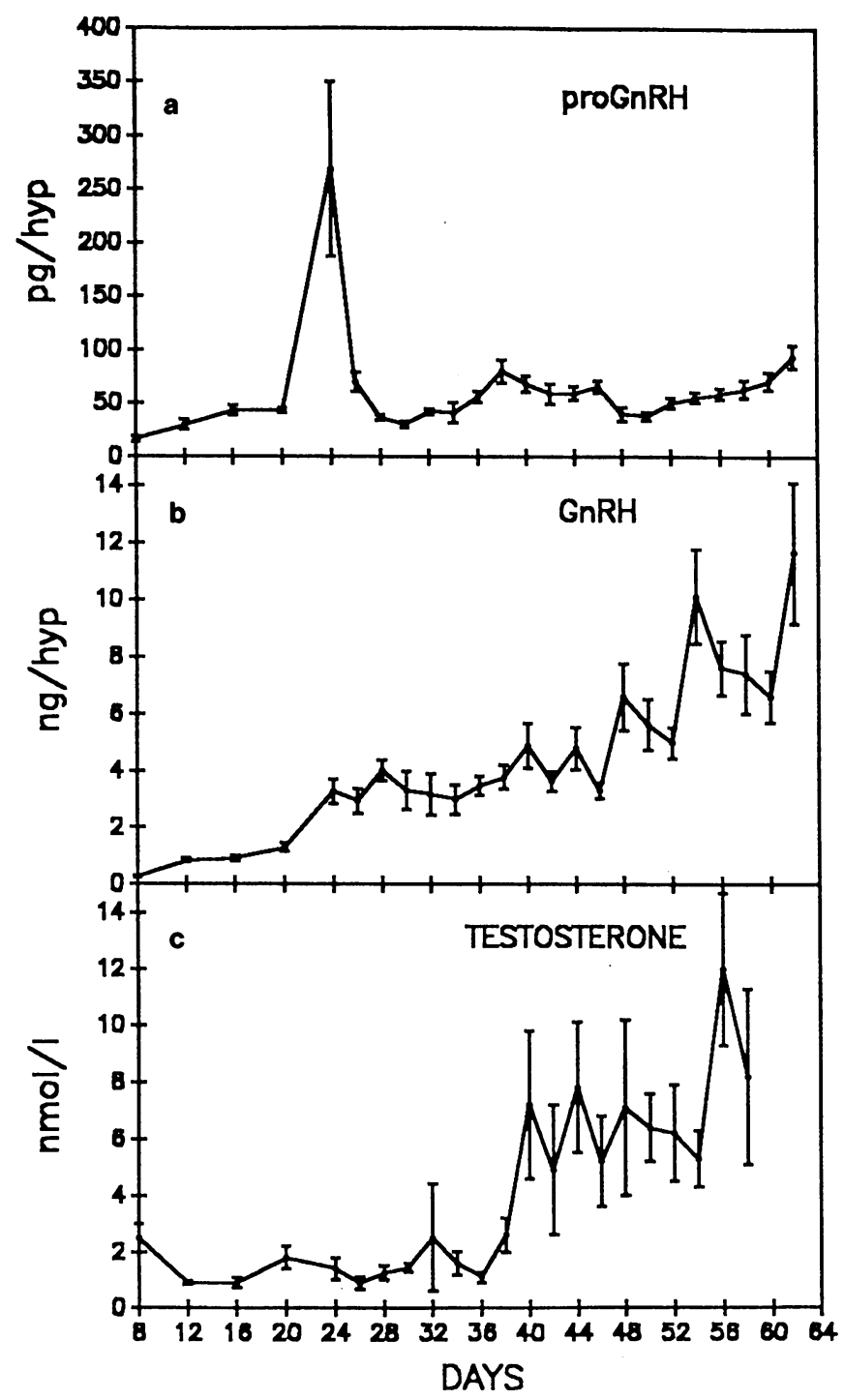

Figure 1. Hypothalamic proGnRH and GnRH content and serum testosterone levels during male rat development. Samples were collected and assayed every $4 \mathrm{~d}$ initially (postnatal days 8-24) and subsequently every $2 \mathrm{~d}$ (days 26-62). Each value is the mean \pm SEM of five to six observations for individual litter mates. Day 24 proGnRH was significantly higher than on all other days $(P<0.05)$.

A significant (approximately sevenfold) increase in GnRH precursor content was observed on postnatal day 24 . The level of GnRH precursor then declined by day 26 to infantile levels. Fully processed GnRH increased in the hypothalamus (approximately threefold above infantile levels) on day 24 . These values were maintained until about day 40 , whereupon another gradual increase was observed throughout the peripubertal period.

Mean serum testosterone levels remained unchanged throughout the infantile, juvenile, and early peripubertal period. On day 40 an increase of approximately threefold was observed. This was maintained throughout the peripubertal period. Serum androstenedione was unchanged throughout the study (results not shown).

The ratio of $\mathrm{GnRH}$ precursor to $\mathrm{GnRH}$ was high until day 24 (when it was at its highest) and declined to low levels from

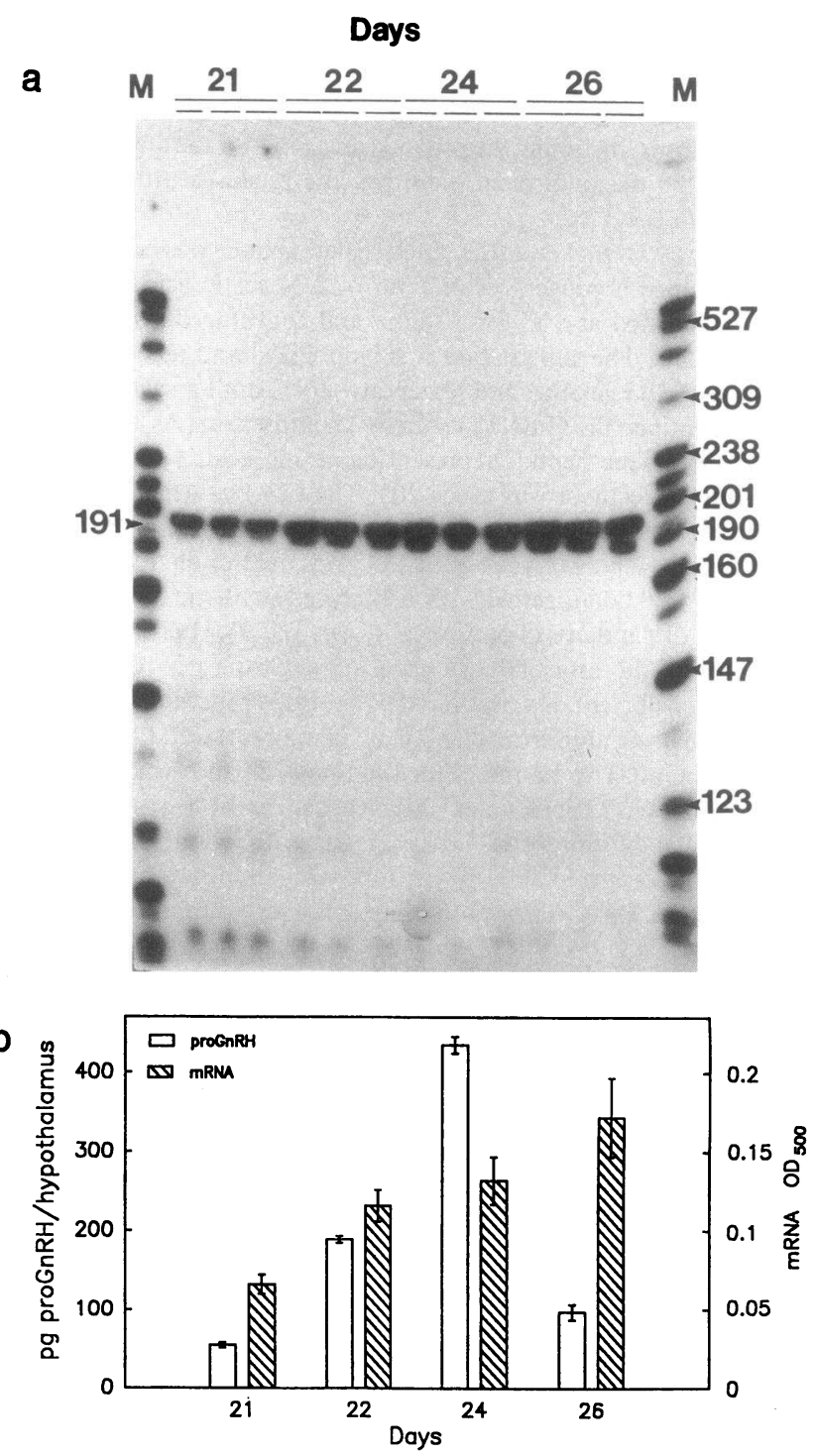

Figure 2. Ratio of GnRH precursor/GnRH during male rat development. The mean mass of each peptide as measured by RIA (Fig. 1) was used to determine the ratio. Maturation of processing can be observed on day 26 when the $\mathrm{GnRH}$ precursor/GnRH ratio is decreased.

day 26 onwards (Fig. 3). This reflects maturation of the precursor processing system between days 24 and 26.

The more detailed study of the changes in GnRH precursor immediately after weaning showed that precursor levels increase on day 22 and confirmed that they are maximal on day 24 and decline by day 26 (Fig. 2). Furthermore, in another experiment, the GnRH precursor content was shown to have already declined in three groups of five animals (sampled on day 25 ) (Table I). Overall, the studies showed an increase in GnRH precursor $1 \mathrm{~d}$ after weaning (day 22), a peak on day 24 , and a rapid decline from day 25 .

GnRH mRNA levels in the hypothalamus are higher on day 22 and remain increased throughout the period studied (Fig. 2). This was confirmed by applying the PCR-based GnRH mRNA assay to day 23 and 25 male rat hypothalami ( Table I). Northern blots of POA RNA from day 20 and day 24 rats, probed with a rat GnRH antisense RNA probe (Fig. 4), also demonstrated the increase in GnRH mRNA at this early 
Table I. Early Juvenile Male Rat GnRH mRNA and GnRH Precursor Quantitation

\begin{tabular}{lccc}
\hline & Day 21 & \multicolumn{1}{c}{ Day 23 } & Day 25 \\
\hline GnRH mRNA (OD $\left.{ }_{500} U\right)$ & $0.098 \pm 0.026$ & $0.161 \pm 0.013$ & $0.160 \pm 0.009$ \\
GnRH precursor $(\mathrm{pg})$ & $54.2 \pm 2.6$ & $298.6 \pm 5.6$ & $226.4 \pm 10.2$ \\
\hline
\end{tabular}

Silver grains eluted from autoradiograph bands representing amplified cDNA (and therefore starting mRNA) were suspended in 30\% glycerol and quantitated by $\mathrm{OD}_{500}$ measurement. GnRH precursor was measured by RIA with antiserum 1947 . Mean values are expressed \pm SEM for observations for three pools of RNA or peptide extract, each from five male rat hypothalami. Days 23 and 25 values were significantly higher than day 21 values $(P<0.05)$.

point in the juvenile period. The two experiments using the PCR-based mRNA assay (Fig. 2; Table I) and the Northern blot result (Fig. 4) are fully supportive of an increase in GnRH gene expression immediately after day 21 weaning of male rats. The increase in GnRH precursor seen on day 24 in Fig. 1 was confirmed by the more detailed studies (Fig. 2; Table I) and correlates directly with the increase in GnRH mRNA shown by the two experiments using the PCR-based assay and the Northern blot assay. Thus, gene transcription (mRNA) increases early in the juvenile period (day 22), resulting in increased translation (GnRH precursor) on day 22 and subsequently in the maturing of the processing efficiency $(\mathrm{GnRH})$ on days 25 and 26.

\section{Discussion}

The majority of studies on the neuroendocrine events preceding and initiating puberty in male rats have focused on the period immediately before the rise in testicular testosterone (around days 38-40) (7, 8, 10, 28-30). The higher serum luteinizing hormone $(\mathrm{LH})$ baseline and pulse amplitude seen at the onset of puberty is a reflection of both the higher levels of GnRH secreted into the portal vessels $(28,29)$ and the increased sensitivity of the pituitary to sex steroids at this time (28-30).

The present study has shown that $\mathrm{GnRH}$ gene expression is increased on day 22 at an earlier stage in development than that

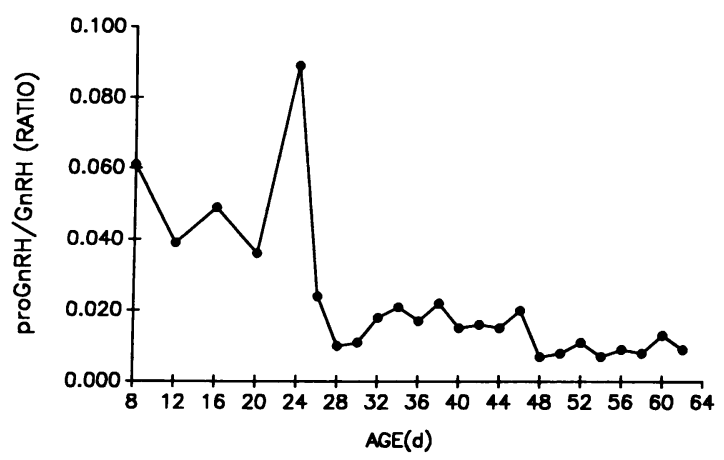

Figure 3. Hypothalamic GnRH mRNA and precursor levels in juvenile male rats (postnatal days 21-26). (a) Autoradiogram of cDNA product from PCR assay of GnRH mRNA. The product in each tract represents the quantitation of GnRH mRNA from $2 \%$ of the extract of five hypothalami (i.e., $10 \%$ of a hypothalamus). (b) Quantitation of proGnRH (RIA) and GnRH mRNA (PCR autoradiograph, silver grain $O D)$. Each value is the mean \pm SEM of observations for three individual pools of hypothalamic extracts each from five litter mates. Day 24 proGnRH was significantly higher than on all other days $(P$ $<0.001)$. Day $26 \mathrm{GnRH}$ mRNA was significantly higher than on day $21(P<0.05)$. M, MspI-digested pBR 322 DNA. at which the frequency of pulsatile $\mathrm{GnRH}$ release increases (day 25) (12, 17). GnRH mRNA and proGnRH were increased at day 22, $1 \mathrm{~d}$ after weaning. Processed GnRH increased on day 24 , which appears to be due to a later maturation of the GnRH processing system. The increase of GnRH biosynthesis at this stage probably results in the increase in GnRH pulsatility seen on day 25 . Three enzymes are required for complete processing of GnRH from its precursor and a deficiency in any one of these could account for the delay. An endoprotease initially cleaves the dibasic amino acid sequence (LysArg) between GnRH and GnRH-associated peptide, followed by carboxypeptidase removal of the basic amino acid residues and then amidation by peptidyl glycine $\alpha$-amidating monooxygenase $(31,32)$.

During the juvenile period (days 21-32), male rat plasma follicle-stimulating hormone (FSH) levels increase (8). After day 32, plasma FSH drops steadily throughout the peripubertal period. Plasma LH levels, although low, become pulsatile around day 25 (33-36). The present study demonstrates that the increases in FSH release during the juvenile period and in LH pulsatility on day 25 may be the consequence of the observed increase in GnRH gene expression after day 21. Jakubowski et al. (19) have shown an increase in GnRH in day 30 male rats compared with day 15 , but since they did not examine the intervening period between these $2 \mathrm{~d}$, they did not observe the day 22 increase that was observed by us.

By the end of juvenile development (around day 40), the LH pulse profile has a higher baseline and the LH pulses in the afternoon are higher than those in the morning; these events are viewed as the first neuroendocrine manifestation of the

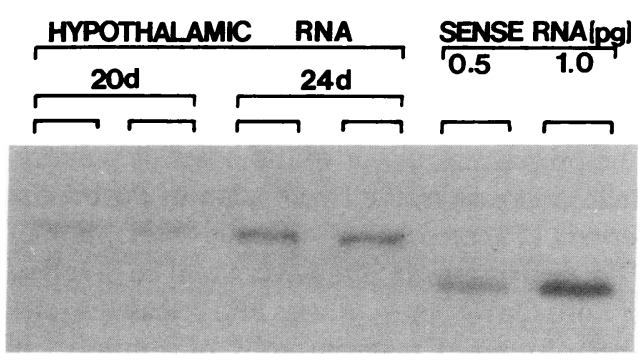

Figure 4. Northern blot of GnRH mRNA in early juvenile rats. The total hypothalamic RNA from four litter mates was loaded into each well of a denaturing agarose gel, subjected to electrophoresis, and blotted onto Hybond $\mathrm{N}+$ (Amersham Corp.) membrane and probed with synthetic antisense rat $\mathrm{GnRH}$ riboprobe $\left(\sim 10^{9} \mathrm{cpm} / \mu \mathrm{g}\right)$. Synthetic truncated sense GnRH mRNA was run as control. Densitometric scanning of the autoradiogram gave the following results: hypothalamic RNA, 20 d: 3,873 and 3,687 U; 24 d: 8,295 and 8,033 $\mathrm{U}$; sense RNA, $0.5 \mathrm{pg}$ : 5,433 $\mathrm{U}$ and $1.0 \mathrm{pg}: 9,080 \mathrm{U}$. 
onset of puberty (36). This appears to be related to the secondary increase in hypothalamic levels of processed $\mathrm{GnRH}$ that we noted after day 40 .

Infantile rats (preweaning) are much less sensitive to the negative feedback of sex steroids on $\mathrm{LH}$ release $(37,38)$ than juvenile rats (39-42). One of the reasons for this is that in infants there are high serum levels of $\alpha$-fetoprotein, which binds sex steroids (43). As $\alpha$-fetoprotein levels decrease in the juvenile animal, more steroid becomes available to extragonadal tissues and the effectiveness of the steroid as a negative feedback agent increases $(38,42,43)$. The results of our study are consistent with the gonadostat hypothesis in that they support the thesis that the effectors of the chronometer (gonadal steroids) are dependent on the prepubertal development and maturation (biosynthesis and release capacities) of the initiator (hypothalamic GnRH) (for reviews see references 1-7). What occurs during the juvenile period could thus be compared with an adult feedback cycle.

A number of neuroendocrine factors could be responsible for the increase in GnRH gene transcription observed immediately after weaning. These include neuropeptide Y (NPY), glutamate, opiates, and growth factors.

NPY may be an affector of GnRH biosynthesis and release both before and during puberty onset (44). During the infantile period immunoreactive NPY levels in the POA increase until weaning, whereupon the levels are maintained throughout the juvenile period (44). This may therefore be responsible for the increase in GnRH biosynthesis observed in our study after day 21 . A further increase in hypothalamic immunoreactive NPY content and increased release from the hypothalamus into the portal vessels are observed with the onset of puberty (on about day 40) (44), corresponding with the secondary increase in GnRH content shown here. Exogenously administered NPY has been shown to stimulate GnRH release from the medial basal hypothalamus $(45,46)$. NPY also increases GnRH-induced secretion of LH in vitro (47-49). Whether NPY affects GnRH biosynthesis, as suggested by this study, remains to be determined.

The excitatory amino acid glutamate increases $\mathrm{GnRH}$ release from the hypothalamus via a receptor-mediated process (50). These receptors increase in the juvenile period (around day 25) (17). Furthermore, the inhibitory autofeedback of GnRH on pulsatility $(16,51)$ appears to be reduced in potency by the glutamate agonist $N$-methyl-D-aspartic acid (18). Since the neurons secreting glutamate are transiently activated in the early juvenile period (17), and since there is an increased frequency of pulsatile GnRH secretion at this stage $(12,16,17)$, glutamate may be primary regulator of the onset of puberty. Since the glutamate increase in the hypothalamus during the early juvenile period (17) corresponds with our observation of increased GnRH gene expression, it may very well be involved in the control of both GnRH biosynthesis and release.

GnRH has been found in maternal milk of a number of mammals, including rats, and is absorbed through the gastrointestinal tract (52-54). A possible reason for increased GnRH gene transcription in weaned rats could be that it is a response by the hypothalamus of the weaned rat to the termination of the maternal source of the hormone. Since milk-borne GnRH has been implicated in ovarian steroidogenesis in infantile rats (54), this proposal deserves investigation.

Two other explanations for increased GnRH gene transcription after weaning may be advanced. First, the phenome- non be a stress-induced response to weaning, mediated by endogenous opiates that are known to affect GnRH release and pulsatility (55-57). Second, the increased GnRH gene transcription may be a temporal phenomenon dependent on a number of preceding developmental events. Thus, normal somatic growth, resulting from growth factor production during the late infantile period and early juvenile period, may be responsible. Growth hormone-releasing factor is required for FSH production and puberty onset in rats (58), and transforming growth factor-alpha released from rat POA-anterior hypothalamus lesions induces precocious puberty in juvenile rats (59).

Thus, there are a number of candidate neuroendocrine factors that are known to affect GnRH release during development and could also be responsible for activating $\mathrm{GnRH}$ gene expression. Investigation of their effects on GnRH gene expression by the techniques described here could provide further insight into the central control of puberty onset. Delineation of the role of these factors in GnRH biosynthesis and release may allow clarification of the underlying pathophysiology of delayed and precocious puberty in man.

\section{Acknowledgments}

We thank S. Blahser, Giessen, Germany, for the gift of antiserum 80/1; J. L. Roberts, Mt. Sinai Hospital, New York, for the GT1-7 cell line; and R. Milton for synthetic peptides. Julia Adams and John Morta are thanked for excellent technical assistance and Lucille Odes for manuscript preparation.

The Medical Research Council, the National Cancer Association, the Foundation for Research Development, and the University of Cape Town provided support for these studies.

\section{References}

1. Ramirez, V. D., and S. M. McCann. 1963. Comparison of the regulation of luteinizing hormone (LH) secretion in immature and adult rats. Endocrinology. 72:452-464.

2. Reiter, E. O., and M. M. Grumbach. 1982. Neuroendocrine control mechanisms and the onset of puberty. Annu. Rev. Physiol. 44:595-613.

3. Plant, R. M. 1983. Ontogeny of gonadotropin secretion in the Rhesus macaque (Macaca mulatta). In Neuroendocrine Aspects of Reproduction. R. L. Norman, editor. Academic Press, New York.

4. Foster, D. L., D. M. Olster, and S. Yellon. 1985. Introduction. In Adolescence in Females. S. Venturoli, C. Flamigni, and J. R. Givens, editors. Year Book Medical Publishers, Chicago.

5. Ojeda, S. R., S. S. Smith-White, H. F. Urbanski, and L. I. Aguado. 1984. The onset of female puberty: underlying neuroendocrine mechanisms. Neuroendocr. Perspect. 3:225.

6. Ojeda, S. R., H. F. Urbanski, and C. E. Ahmed. 1986. The onset of female puberty: studies in the rat. Recent Prog. Horm. Res. 42:385-442.

7. Ojeda, S. R., H. F. Urbanski, C. E. Ahmed, L. Rogers, and D. Gonzalez. 1988. Physiological and biochemical dissection mechanisms underlying puberty. In Endocrinology and Physiology of Reproduction. P. C. K. Leung, D. T. Armstrong, K. B. Ruf, W. H. Moger, and H. G. Friesen, editors. Plenum Publishing Corporation, New York. 113-126.

8. Payne, A. H., R. P. Kelch, and E. P. Murono. 1977. Hypothalamic, pituitary and testicular function during sexual maturation of the male rat. J. Endocrinol. 72:17-26.

9. Ketelslegers, J. M., W. D. Hetzel, R. J. Sherins, and K. J. Catt. 1978. Developmental changes in testicular gonadotropin receptors: plasma gonadotropins and plasma testosterone in the rat. Endocrinology. 103:212-222.

10. Chaiappa, S. A., and G. Fink. 1977. Releasing factor and hormonal changes in the hypothalamic pituitary gonadotrophin and adrenocorticotrophin systems before and after birth and puberty in male, female and androgenized female rats. J. Endocrinol. 72:211-214.

11. Bourguignon, J. P., A. Gerard, and P. Franchimont. 1984. Age-related differences in the effect of castration upon hypothalamic LHRH content in male rats. Neuroendocrinology. 38:376-381.

12. Bourguignon, J. P., and P. Franchimont. 1984. Puberty-related increase in episodic LHRH release from rat hypothalamus in vitro. Endocrinology. 114:1943-1945. 
13. Wildt, L., A. Hausler, G. Marshall, G. S. Hutchinson, T. M. Plant, B. E. Belchetz, and E. Knobil. 1981. Frequency and amplitude of gonadotropin-releasing hormone stimulation and gonadotropin secretion in the rhesus monkey. Endocrinology. 109:376-385.

14. Huffman, L. J., E. K. Inskeep, and R. L. Goodman. 1987. Changes in episodic luteinizing hormone secretion leading to puberty in the lamb. Biol. Reprod. 37:755-761.

15. Rodriguez, R. E., and M. E. Wise. 1989. Ontogeny of pulsatile secretion of gonadotropin-releasing hormone in the bull calf during infantile and pubertal development. Endocrinology. 124:248-256.

16. Valenca, M. M., C. A. Johnston, M. Ching, and A. Negro Villar. 1987. Evidence for a negative ultrashort loop feedback mechanism operating on luteinizing hormone-releasing hormone neuronal system. Endocrinology. 121:22562259.

17. Bourguignon, J. P., A. Gerard, J. Mathieu, A. Mathieu, and P. Franchimont. 1990. Maturation of the hypothalamic control of pulsatile gonadotropinreleasing hormone secretion at onset of puberty. I. Increased activation of $\mathrm{N}$ methyl-D-aspartate receptors. Endocrinology. 127:873-881.

18. Bourguignon, J. P., A. Gerard, and P. Franchimont. 1990. Maturation of the hypothalamic control of pulsatile gonadotropin-releasing hormone secretion at onset of puberty. II. Reduced potency of an inhibitory autofeedback. Endocrinology. 127:2284-2891.

19. Jakubowski, M., M. Blum, and J. L. Roberts. 1991. Postnatal development of gonadotropin-releasing hormone and cyclophilin gene expression in the female and male rat brain. Endocrinology. 128:2702-2708.

20. Roberts, J. L., C. M. Dutlow, M. Jakubowski, M. Blum, and R. P. Millar. 1989. Estradiol stimulates preoptic area: anterior hypothalamic proGnRH-GAP gene expression in ovariectomized rats. Mol. Brain Res. 6:127-134.

21. Kelly, M. J., J. Garret, M. A. Bosch, C. E. Rosell, J. Douglass, J. P. Adelman, and O. K. Ronnekleiv. 1989. Effects of ovariectomy on GnRH $\mathrm{mRNA}$, proGnRH and GnRH levels in the preoptic hypothalamus of the female rat. Neuroendocrinology. 49:88-97.

22. King, J. A., C. J. Tobler, R. W. Roeske, W. A. Day, J. E. Rivier, and R. P Millar. 1983. A radioimmunoassay specific for [Gln8] LH-RH: application in the confirmation of the structure of chicken hypothalamic luteinizing hormone-releasing hormone. Peptides (NY). 4:883-887.

23. Millar, R. P., and C. Kewley. 1976. Production of a specific antiserum for testosterone. S. Afr. Med. J. 50:1021-1022.

24. King, J. C., G. Kugel, D. Zahniser, K. Wooledge, D. A. Dammmasson, and B. Alexsavich. 1987. Changes in populations of LHRH-immunopositive cell bodies following gonadectomy. Peptides (NY). 8:721-735.

25. Ronnekleiv, O. K., and M. J. Kelly. 1986. Luteinizing hormone-releasing hormone neuronal system during the estrous cycle of the female rat: effects of surgically induced persistent estrus. Neuroendocrinology. 43:564-576.

26. Chomczynski, P., and N. Sacchi. 1987. Single-step method of RNA isolation by acid guanidinium thiocyanate-phenol-chloroform extraction. Anal. Biochem. 162:156-159.

27. Goblet, C., E. Prost, and R. G. Whalen. 1989. One step amplification of transcripts in total RNA using the polymerase chain reaction. Nucleic Acids Res. 17:2144.

27a. Suissa, M. 1983. Quantitation of silver grains from fluorograms. Anal. Biochem. 133:511-514.

28. Sarkar, D. K., and G. Fink. 1979. Mechanisms of the first spontaneous gonadotropin surge and that induced by pregnant mare serum and effects of neonatal androgen in rats. J. Endocrinology. 83:339-354.

29. Sarkar, D., and N. Mitsugi. 1988. Correlative changes of GnRH associated peptide (GAP) and GnRH immunoreactivities in the hypothalamus and pituitary portal plasma during neonatal and pubertal periods of rats. Endocrinology. 122 (Suppl.):24. (Abstr. 13.)

30. Castro-Vasquez, A., and S. Ojeda. 1977. Changes in pituitary responsiveness to LH-RH during puberty in the female rat: initiation of the priming event. Neuroendocrinology. 23:88-98.

31. Wetsel, W. C., M. D. Culler, A. Johnson, and A. Negro-Vilar. 1988. Processing of the luteinizing hormone-releasing hormone precursor in the preoptic area and hypothalamus of the rat. Mol. Endocrinol. 2:22-31.

32. Rangaraju, N. S., J.-F. Xu, and R. B. Harris. 1991. Pro-gonadotropin-releasing hormone is processed within hypothalamic neurosecretory granules. Neuroendocrinology. 53:20-28.

33. Kronibus, J., and W. Wuttke. 1977. Positive feedback of estradiol on gonadotropin release in 15 day old rats. Acta Endocrinol. 86:263-272.

34. Kimura, F., and W. Kawakami. 1982. Epidodic LH secretion in the immature male and female rat as assessed by sequential blood sampling. Neuroendocrinology. 35:128-132.

35. Andrews, W. W., and S. R. Ojeda. 1981. A detailed analysis of the serum LH secretory profiles of conscious, free-moving female rats during the time of puberty. Endocrinology. 109:2032-2039.
36. Urbanski, H., and S. R. Ojeda. 1985. The juvenile-peripubertal transition period in the female rat: establishment of a diurnal pattern of pulsatile luteinizing hormone secretion. Endocrinology. 117:644-649.

37. Andrews, W. W., and S. R. Ojeda. 1977. On the feedback actions of estrogen on gonadotropins and prolactin release in infantile female rats. Endocrinology. 101:1517-1523.

38. Meijs-Roelofs, H. M. A., and P. Kramer. 1979. Maturation of the inhibitory feedback action of estrogen on follicle-stimulating hormone secretion in the immature female rat: a role for alpha-fetoprotein. J. Endocrinol. 81:199-208.

39. Steele, R. E., and J. Weisz. 1974. Change in sensitivity of estradiol-LH feedback system with puberty in the female rat. Endocrinology. 95:513-520.

40. Eldridge, J. C., J. C. McPherson III, and V. B. Mahesh. 1974. Maturation of the negative feedback control of gonadotropin secretion in the female rat. Endocrinology. 94:1536-1540.

41. Andrews, W. W., and S. R. Ojeda. 1981. A quantitative analysis of the maturation of steroid negative feedbacks controlling gonadotropin release in the female rat: transition from an androgenic to a predominantly estrogenic control. Endocrinology. 108:1313-1320.

42. Andrews, W. W., J. P. Advis, and S. R. Ojeda. 1981. The maturation of estradiol negative feedback in female rats: evidence that the resetting of the hypothalamic "gonadostat" does not precede the first preovulatory surge of gonadotropins. Endocrinology. 109:2022-2031.

43. Germain, J., P. S. Campbell, and J. N. Anderson. 1978. Role of the serum estrogen-binding protein in the control of tissue estradiol levels during post-natal development of the female rat. Endocrinology. 103:1401-1410.

44. Sutton, S. W., N. Mitsugi, P. M. Plotsky, and D. Sarkar. 1988. Neuropeptide Y (NPY): a possible role in the initiation of puberty. Endocrinology. 123:2152-2154.

45. Khorram, O., K. Y. Francis Pau, and H. G. Spies, H. G. 1987. Bimodal effects of neuropeptide $Y$ on hypothalamic release of gonadotropin-releasing hormone in conscious rabbits. Neuroendocrinology. 45:290-297.

46. Crowley, W. R., and S. P. Kalra. 1987. Neuropeptide Y stimulates the release of luteinizing hormone-releasing hormone from medial basal hypothalamus in vitro: modulation by ovarian hormones. Neuroendocrinology. 46:97-103.

47. Kerkerian, L., J. Guy, G. Le Fevre, and G. Pelletier. 1985. Effects of neuropeptide Y (NPY) on the release of anterior pituitary hormones in the rat. Peptides (NY). 6:1201-1204.

48. Crowley, W. R., A. Hassid, and S. P. Kalra. 1987. Neuropeptide Y enhances the release of luteinizing hormone $(\mathrm{LH})$ induced by $\mathrm{LH}$-releasing hormone. Endocrinology. 120:941-945.

49. McDonald, J. K., M. D. Lumpkin, W. K. Samson, and S. M. McCann. 1985. Neuropeptide $Y$ affects secretion of luteinizing hormone and growth hormone in ovariectomized rats. Proc. Nat. Acad. Sci. USA. 82:561-564.

50. Donoso, A. O., F. J. Lopez, and A. Negro Villar. 1990. Glutamate receptors of the non-N-methyl-D-aspartic acid type mediate the increase in luteinizing hormone releasing hormone release by excitatory amino acids in vitro. Endocrinology. 126:414-420.

51. De Paola, L. V., R. A. King, and A. Carillo. 1987. In vivo and in vitro examination of an autoregulatory mechanism for luteinizing hormone releasing hormone. Endocrinology. 120:272-279.

52. Baram, T., Y. Koch, E. Hazum, and M. Fridkin. 1977. Gonadotropin-releasing hormone in milk. Science (Wash. DC). 198:300-302.

53. Sarda, A. K., and R. M. G. Nair. 1981. Elevated levels of LRH in human milk. J. Clin. Endocrinol. \& Metab. 52:826-828.

54. Smith, S. S., and S. R. Ojeda. 1984. Maternal modulation of infantile ovarian development and available luteinizing hormone-releasing hormone LHRH receptors via milk LHRH. Endocrinology. 115:1973-1983.

55. Sarkar, D. K., and S. S. C. Yen. 1985. Hyperprolactinemia decreases the luteinizing hormone-releasing hormone concentration in pituitary portal plasma: a possible role for endorphin as a mediator. Endocrinology. 116:2080-2084.

56. Karahalios, D. G., and J. E. Levine. 1988. Nalaxone stimulation of in vivo LHRH release is not diminished following ovariectomy. Neuroendocrinology. 47:504-510.

57. Leposavic, G., P. O. Cover, and J. C. Buckingham. 1991. In vivo and in vitro studies on the opioidergic control of secretion of gonadotrophin-releasing hormone and luteinizing hormone in sexually immature and adult male rat. Neuroendocrinology. 53:579-588.

58. Garnello, T. E., P. L. Sanchez Franco, L. Cacicedo, and E. Arguilar. 1990 Puberty onset, somatic growth and follicle stimulating hormone (FSH) secretion in female rats immunized against growth hormone-releasing hormone (GRF), insulin-like growth factor I (IGF-I) and vasoactive intestinal peptide (VIP). Neuroendocrinology. 52:P 3, 60. (Abstr.)

59. Junier, M. P., M. E. Costa, G. Hoffman, D. F. Hill, and S. R. Ojeda. 1990 Transforming growth factor (TGF) mediates hypothalamic lesion-induced precocious puberty in the female rat. Neuroendocrinology. 52:P 4, 60. (Abstr.) 